\title{
ASSESSING PSYCHOSOCIAL DISTRESS IN BONE METASTASES TREATED WITH ENDOPROSTHESIS
}

\author{
AVALIAC̣ÃO DA ANGÚSTIIA PSICOSSOCIAL NA METÁSTASE \\ ÓSSEA TRATADA COM ENDOPRÓTESE
}

\author{
lucas Santiago ${ }^{1}$, Pedro Reggiani anzuatégul ${ }^{2}$, José Paulo Agner Ribeiro ${ }^{1}$, Maurício Carrilho Filon ${ }^{1}$, \\ Glauco José Pauka Mello ${ }^{2}$, ana Valéria Brunetti Rigolino ${ }^{2}$
}

1. Universidade Positivo, Faculdade de Medicina, Curitiba, PR, Brazil.

2. Hospital Erasto Gaertner, Orthopedic Oncology Service, Curitiba, PR, Brazil.

\section{ABSTRACT}

Objective: To compare preoperative and early postoperative levels of psychosocial distress in patients undergoing bone metastasis treatment with endoprosthesis, evaluating its impact on quality of life. Methods: Thirteen patients undergoing endoprosthetic treatment of bone metastasis were assessed at two time points: preoperatively and 30 days postoperatively. The tool used was the Distress Thermometer, a questionnaire for psychosocial screening developed by the National Comprehensive Cancer Network. Distress is considered moderate or severe if the patient scores 4 or higher. Results: The most frequent problems in the preoperative period were "bathing and dressing". At 30 days, "fatigue" and "nervousness" prevailed. There was a significant improvement in distress when preoperative and 30-day assessments were compared. Conclusion: The surgical treatment of bone metastasis with endoprosthesis results in an early improvement of psychosocial distress as measured by the Distress Thermometer. Level of evidence II, Prospective and comparative therapeutic study.

Keywords: Quality of Life. Bone Neoplasms. Neoplasm Metastasis. Surgical Oncology.

\section{RESUMO}

Objetivo: Confrontar o nível de angústia psicossocial (distress) entre o pré-operatório e o pós-operatório precoce de pacientes submetidos ao tratamento de metástase óssea com endoprótese, avaliando seu impacto na qualidade de vida. Métodos: Foram avaliados 13 pacientes submetidos ao tratamento de metástase óssea com endoprótese em dois momentos: pré-operatório e pós-operatório de 30 dias. A ferramenta utilizada foi o termômetro de Distress, questionário de triagem psicossocial desenvolvido pela National Comprehensive Cancer Network. É considerado distress moderado ou grave se o paciente somar 4 ou mais pontos. Resultados: No pré-operatório, os problemas mais frequentes foram "tomar banho e vestir-se". Com 30 dias, os itens mais prevalentes foram "cansaço" e "nervosismo". Houve melhora significativa do distress quando foram comparadas as avaliações pré-operatória e após 30 dias. Conclusão: O tratamento cirúrgico com endoprótese para metástase óssea reduz precocemente o nível de angústia psicossocial aferido pelo termômetro de Distress. Nível de evidência II, Estudo terapêutico, prospectivo e comparativo.

Descritores: Qualidade de Vida. Neoplasias Ósseas. Metástase Neoplásica. Oncologia Cirúrgica.

Citation: Filon MC, Anzuatégui PR, Ribeiro JPA, Santiago L, Mello GJP, Rigolino AVB. Assessing psychosocial distress in bone metastases treated with endoprosthesis. Acta Ortop Bras. [online]. 2019;27(5):257-60. Available from URL: http://www.scielo.br/aob.

\section{INTRODUCTION}

According to the most recent global estimates, the three most common types of tumor in the population have a high prevalence of metastatic bone disease as they progress. Factors such as comorbidities associated with the underlying disease, risk of surgical treatment, and great variability in patient survival make bone metastasis treatment a challenge to the orthopedic oncologist. ${ }^{1-3}$ There are two main types of surgical treatment for this type of neoplastic lesion: open reduction with internal fixation or endoprosthetic replacement. Both are effective when the bone neoplasm has high risk or presence of fracture, and lead to an important improvement in pain, quality of life, and function. However, there is no consensus in the literature regarding which technique is superior. ${ }^{3-5}$ This study assesses the surgical treatment using endoprosthetic replacement, which is the method of choice at our Service.

Most authors consider improvement in pain and function to be a determinant factor for a successful surgery, but few of them focus on quality of life. ${ }^{3,6}$ When assessing quality of life, one of the parameters that can be included is psychosocial distress, which refers, in general terms, to all types of stress faced by the patient with cancer during treatment, being considered the sixth vital sign in cancer care. ${ }^{7}$

There are many tools that can be used to assess level of distress, such as the Beck Depression Inventory, the Hospital Anxiety and

All authors declare no potential conflict of interest related to this article.

Work conducted at the Orthopedic Oncology Service, Hospital Erasto Gaertner, Curitiba, PR, Brazil.

Correspondence: Pedro Reggiani Anzuatégui. Rua Ari José Valle, 980/16, Curitiba, PR, Brazil. 82030-000. pedroanzuategui@hotmail.com 
Depression Scale, the Short-Form General Health Survey (SF36), and the National Cancer Comprehensive Cancer Network (NCCN) Distress Thermometer. The latter was the one chosen by the researchers. ${ }^{7,8}$

Studies investigating the association of surgical treatment of bone metastasis in the appendicular skeleton with patients' level of distress were not found in the literature, even though its influence on treatment adherence and duration is known. 9,10,11This knowledge gap prompted us to perform the present study, whose aim was to determine the impact of endoprosthetic treatment on the level of distress of patients with bone metastasis.

\section{MATERIALS AND METHODS}

A prospective analysis of a series of consecutive patients with metastatic bone disease who were surgically treated with endoprosthesis was made. The study was approved by the relevant ethics committee (CAEE: 65673317.9.0000.0098), and all participants were properly informed about the study methodology and provided consent by signing an informed consent form. All procedures were in accordance with the ethical standards of the 1995 Helsinki Declaration.

\section{Inclusion criteria}

(1) Patients with appendicular skeletal metastasis undergoing surgical treatment with endoprosthesis; (2) presence of postoperative pathology study confirming the diagnosis of bone metastasis.

\section{Exclusion criteria}

(1) Death before 30 days of surgery; (2) loss to follow-up; (3) incomplete data.

\section{The DT questionnaire}

The DT questionnaire was developed by the NCCN to evaluate the level of distress faced by the patient with cancer during treatment. This tool consists of two parts:the first one shows a visual analogue scale (VAS) of the patient's level of distress at the time of the evaluation, and the second contains a list of problems. (Figure 1) Research participants completed the questionnaire before surgery and 30 days after surgery, during outpatient follow-up. The questionnaire was administered in electronic format, using GoogleForms ${ }^{\circledR}$, and researchers assisted patients during its application.

\section{Distress assessment}

The patients graded their perception about their level of distress with the visual aid of a thermometer ranging from 0 to 10. A score higher than 4 was considered moderate/severe distress. Values below that were considered mild distress.

\section{Problem list}

The problem list consisted of 39 problems divided into five areas as follows: practical problems; family problems; physical problems; emotional problems; and spiritual concerns. Patients answered each problem from the list with "yes" or "no", and the prevalence of each of the problems and their distribution by area were measured.

\section{Statistical analysis}

Epidemiological data were detailed through descriptive statistics. The level of distress reported in the VAS was described as mean value and standard deviation.Statistical significance of the intergroup analysis was determined using one-way analysis of variance (ANOVA). Variation in level of distress (mild or moderate/severe)

\section{SCREENING TOOLS FOR MEASURING DISTRESS}

Instruction: First please circle the number (0-10) that best describes how much distress you have been experiencing in the past week including today.

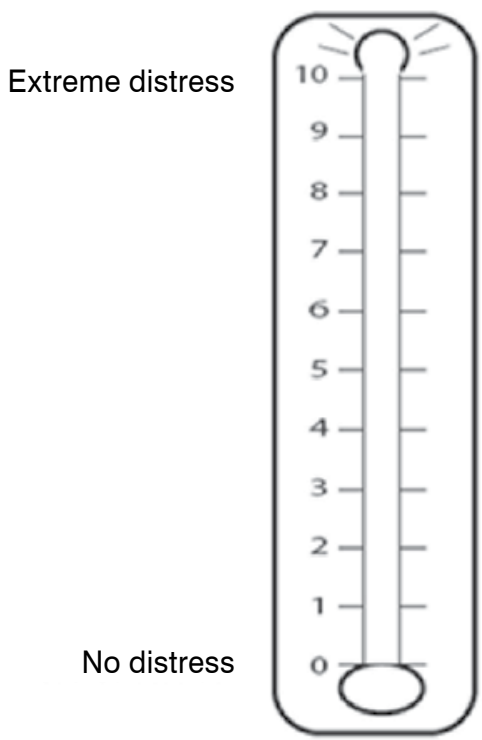

Second, please indicate if any of the following has been a problem for you in the past week including today. Be sure to cheek Yes or No for cach.

\section{Yes No Practical problems \\ $\square \quad$ Child care \\ $\square \quad \square$ Housing \\ $\square \quad \square$ Insurance/financial \\ $\square \quad \square$ Transportation \\ ㅁ Work/scholl \\ $\square \quad \square$ Treatment decisions}

\section{Family problems}

$\square \quad \square$ Dealing with children

$\square \quad \square$ Dealing with partner

$\square \quad$ Ability to have children

$\square \quad$ Family health issues

$\begin{array}{lll} & & \text { Emotional problems } \\ \square & \square & \text { Depression } \\ \square & \square & \text { Fears } \\ \square & \square & \text { Nervousness } \\ \square & \square & \text { Sadness } \\ \square & \square & \text { Worry } \\ \square & \square & \text { Loss of interest in } \\ & \text { usual activities }\end{array}$

$\square \quad \square$ Spititual/religious concerns

Other problems:

\begin{tabular}{|c|c|c|}
\hline les & No & Physical problems \\
\hline$\square$ & $\square$ & Appearance \\
\hline$\square$ & $\square$ & Bathing/dressing \\
\hline$\square$ & $\square$ & Breathing \\
\hline$\square$ & $\square$ & Changes in urination \\
\hline$\square$ & $\square$ & Constipations \\
\hline$\square$ & $\square$ & Diarrhea \\
\hline$\square$ & $\square$ & Eating \\
\hline$\square$ & $\square$ & Fatigue \\
\hline$\square$ & $\square$ & Feeling swollen \\
\hline$\square$ & $\square$ & Fevers \\
\hline$\square$ & $\square$ & Getting around \\
\hline$\square$ & $\square$ & Indigestion \\
\hline$\square$ & $\square$ & Memory/concentration \\
\hline$\square$ & $\square$ & Mouth sores \\
\hline$\square$ & $\square$ & Nausea \\
\hline$\square$ & $\square$ & Nose dry/congested \\
\hline$\square$ & $\square$ & Pain \\
\hline$\square$ & $\square$ & Sexual \\
\hline$\square$ & $\square$ & Skin dry/itchy \\
\hline$\square$ & $\square$ & Sleep \\
\hline$\square$ & $\square$ & Substance abuse \\
\hline$\square$ & $\square$ & Tingling in hands/feet \\
\hline
\end{tabular}

Adapted with permission from the NCCN Clinical Practice Guidelines in Oncology (NCCN Guidelines $®$ ) for Distress Management V.1.2019. (C) 2019 NationalComprehensiveCancer Network, Inc. All rights reserved.

Figure 1. The Distress Thermometer questionnaire. 
was analyzed as dichotomous variable and its significance was determined by the McNemar test.

The variables corresponding to the problems reported by the patients were described as mean value for each item and absolute number of marked items. The total number of problems in each category was presented as mean value, and the intergroup analysis significance was determined using one-way ANOVA.

The confidence interval used was 95\%, and data were tabulated with Microsoft Excel $2018^{\circledR}$. Statistical analysis was performed using MedCalc ${ }^{\circledR}$.

\section{RESULTS}

The initial sample consisted of 21 patients. Five patients died before 30 days of surgery (one due to pulmonary sepsis; one due to urinary sepsis; three due to natural disease progression).There were two losses to follow-up (both patients continued treatment in another institution) and in one case the pathology study showed no bone metastasis. After inclusion and exclusion criteria were observed, 13 patients remained in the study. Table 1 shows the general characteristics of the sample.

\section{Level of distress}

The mean distress score obtained preoperatively was 5.92, reducing to 4 postoperatively (at 30 days) $(p=0.67)$. Figures 2 and 3 show the distribution of the participants' scores in each assessment. There was a reduction in the number of patients with severe/moderate distress from 11 (84\%) to 6 (46\%), with $p=0.06$. (Figure 4) Only two participants performed worse, both with moderate/severe distress.

Table 1. General characteristics of the patients undergoing surgery with endoprosthesis due to appendicular skeletal metastasis.

\begin{tabular}{c|c}
\hline Characteristics & $\mathbf{n}(\%)$ \\
\hline Total sample size & 13 \\
\hline Female sex & $8(62 \%)$ \\
\hline Age (years) & $45.8(12), 39-87$ \\
\hline Primary tumor & $7(53.8 \%)$ \\
\hline Breast & $2(15.3 \%)$ \\
\hline Kidney & $2(15.3 \%)$ \\
\hline Lung & $1(7.7 \%)$ \\
\hline Prostate & $1(7.7)$ \\
\hline Squamous cell carcinoma (oropharynx) & $10(76.9 \%)$ \\
\hline Lesion site & $1(7.6 \%)$ \\
\hline Proximal femur & $1(7.6 \%)$ \\
\hline Distal femur & $1(7.6 \%)$ \\
\hline Proximal humerus &
\end{tabular}

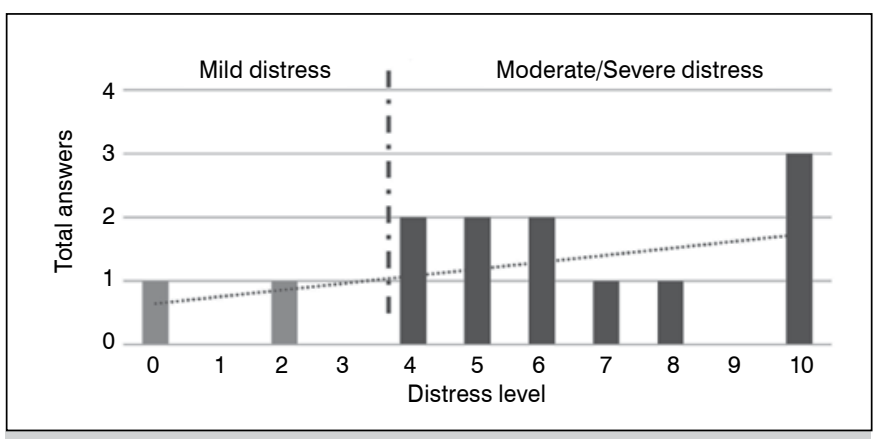

Figure 2. Distribution of Distress Thermometer scores in the preoperativeassessment of patients with appendicular skeletal metastasis.
Problem list

The most prevalent problems in each assessment are presented in Table 2.The proportion of problems by area is shown in Figure 5. Regarding the mean number of problems, there was a reduction from 9 to 7,8 , without statistical significance $(p=0.6)$. In the analysis by area, emotional, family, spiritual, and practical problems had little variation, as observed in Figure 5 ( $p>0.05)$.

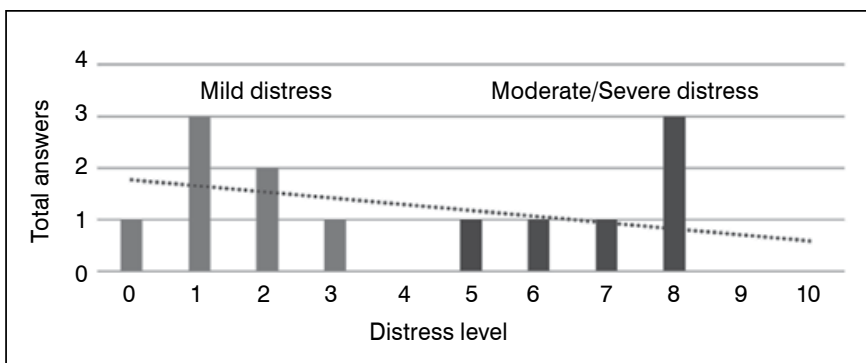

Figure 3. Distribution of Distress Thermometer scores in the 30-day postoperative assessment of patients with appendicular skeletal metastasis treated with endoprosthesis.

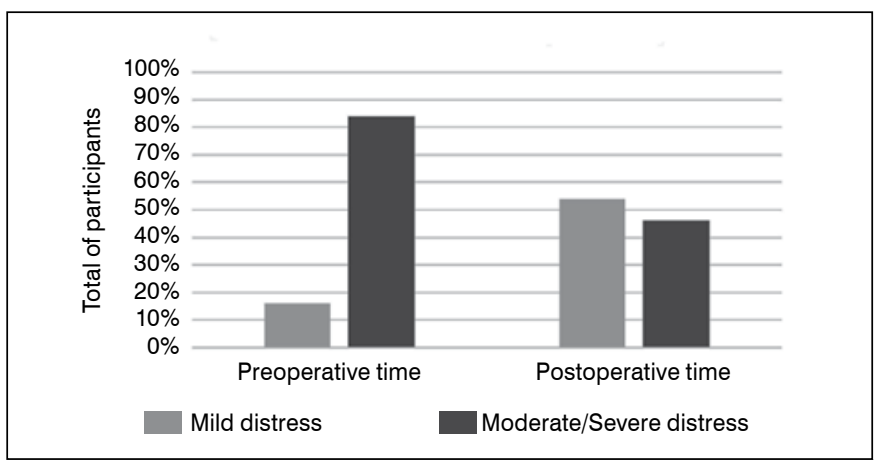

Figure 4. Severity of the level of distress in patients with appendicular skeletal metastasis undergoingsurgical treatment with endoprosthesis.

Table 2. Prevalence of problems reported by patients with appendicular skeletal metastasis in preoperative and 30-day postoperativeassessments.

\begin{tabular}{c|c}
\hline Preoperative & 30-daypostoperative \\
\hline Pain $-76.9 \%$ & Getting around $-61.5 \%$ \\
\hline Skin dry/itchy $-69.2 \%$ & Fatigue $-53.8 \%$ \\
\hline Bathing/dressing $-61.5 \%$ & Skin dry/itchy $-46.2 \%$ \\
\hline Worry $-53.8 \%$ & Worry- $38.5 \%$ \\
\hline Constipation $-53.8 \%$ & Bathing/dressing $-30.8 \%$ \\
\hline
\end{tabular}

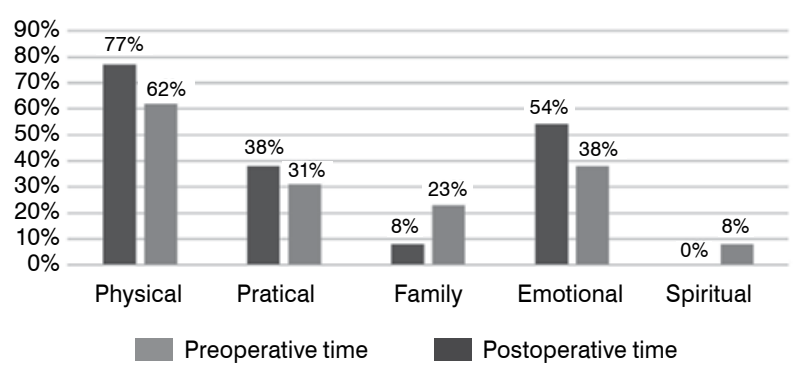

Figure 5. Prevalence of problems by category in patients with appendicular skeletal metastasis. 


\section{DISCUSSION}

Bone metastasis is part of the natural history of the disease in a large proportionof patients with cancer, ranging from one third to one fifth of ill patients in total. ${ }^{12}$ The presence of the lesion is usually associated with pain and reduced mobility, which strongly impact patient's independence, capacity to perform daily activities, and, consequently, quality of life. ${ }^{13} T$ The reconstruction of bone metastases with endoprosthesis is one of the main treatment options for this condition. However, the procedure is not performed frequently, as most tumors are treated conservatively and not all patients are clinically stable enough to undergo a major surgery. Maybe because of that, even in the largest prospective studies found, the total number of surgeries was not superior to 20 a year., 613

Regarding the tool used, the DT was developed in the late 1990s similarly to the pain scale, with scores ranging from 0 to 10 , where values equal to or below 4 indicate need of referral to a psychosocial care service. ${ }^{14}$ Over the years, hospitals included the DT in their clinical protocols. In 2004, the Canadian public health agency recognized distress as the sixth vital sign, along with heart rate, respiration, blood pressure, temperature, and pain. ${ }^{7}$ In the present study, the administration of DT was easy and fast, with good acceptance both by the researchers and by the patients. The use of a broad problem list provides guidance about the measures which may be taken to reduce patients' level of distress. As it encompasses many different areas, the DT also favors the participation of other health professionals in the care of the patient, contributing to an interdisciplinary and comprehensive treatment. ${ }^{15}$

The participants of this study obtained a $30 \%$ reduction in the mean distress scoreas well as a lower frequency of moderate/severe distress in a short time after surgery, showing that reconstruction with endoprosthesis leads toan early improvement in quality of life. (Figures 2, 3, and 4) Such findings are of great importance in individuals that often have low estimated survival.
Direct comparison of our results was not possible because of a lack of similar studies. When we compared groups of patients with different profiles, we found that our preoperative distress score was higher than those found by Tuinman et al. ${ }^{16}$ and Lera et al. ${ }^{17}$ However,scores were similar after surgical intervention, close to a grade 4 distress. Conversely, those authors did not stratify patients according to surgical treatment, which could have provided better grounds for comparison. There was a predominance of pain among the problems reported by the participants preoperatively, when almost $80 \%$ of the sample provided a positive answer to this item. After the reconstruction surgery the percentage reduced to a little less than half of the patients. Both results were above those found in the literature, ${ }^{18}$ which shows that pain is an important component both in preoperative care and in recovery after surgery. Another important finding was the prevalence of physical and emotional problems as reported by the patients in the two assessments. These two categories of problems had the strongest correlation with the reported level of distress, ${ }^{19}$ and in our study more than one third of the patients showed at least one problem in each of these areas.

Because of the severe condition of the evaluated patients, there was a significant number of deaths in less than 30 days of follow-up. This led to a small final sample, which is the main limitation of this study. Our study shows how the treatment of appendicular skeletal metastasis with endoprosthesis may result in an early reduction in the level of distress reported by patients. Knowledge of the most common problems at different times may also better guide the team regarding the pre- and postoperative care of the patient, besides favoring a comprehensive treatment.

\section{CONCLUSION}

Patients undergoing treatment of appendicular skeletal metastasis with endoprosthesis tend to show a reduction inlevel of distress as demonstrated by the DT tool.

AUTHORS' CONTRIBUTIONS: Each author made significant individual contributions to this manuscript. MCF (0000-0002-4402-8895) ${ }^{\star}$ : substantial contribution in the conception and design of the work and acquisition of data for the study; PRA (0000-0002-1813-2242)*: surgeries; acquisition and analysis of data for the study, critical review of the article and participation in the intellectual concept of the article; JPAR (0000-0001-6238-3041)*: acquisition of data for the study; LS (0000-0001-7903-3996)*: acquisition, analysis and interpretation of data for the study, writing of the manuscript and critical review of its intellectual content; GJPM (0000-0002-5877-6472)*: surgeries; critical review of the article and participation in the intellectual concept of the article; AVBR (0000-0002-8492-4774)*: surgery; critical review of the intellectual content of the article. *ORCID (Open Researcher and Contributor ID).

\section{REFERENCES}

1. World Health Organization (WHO). GLOBOCAN 2012: Estimated Cancer Incidence, Mortality and Prevalence Worldwide in 2012 v1.0 [Internet]. 2012 [Accessed in 21 feb 2019]; Available from: http://publications.iarc.fr/Databases/ larc-Cancerbases/GLOBOCAN-2012-Estimated-Cancer-Incidence-Mortality-And-Prevalence-Worldwide-In-2012-V1.0-2012

2. Li S, Peng Y, Weinhandl ED, Blaes AH, Cetin K, Chia VM, et al. Estimated number of prevalent cases of metastatic bone disease in the US adult population. Clin Epidemiol. 2012;4:87-93.

3. Wood TJ, Racano A, Yeung H, Farrokhyar F, Ghert M, Deheshi BM. Surgical management of bone metastases: quality of evidence and systematic review. Ann Surg Oncol. 2014;21(13):4081-9.

4. Ormsby NM, Leong WY, Wong W, Hughes HE, Swaminathan V. The current status of prophylactic femoral intramedullary nailing for metastatic cancer. Ecancermedicalscience. 2016;10:698.

5. Mirels H. Metastatic disease in long bones. A proposed scoring system for diagnosing impending pathologic fractures. Clin Orthop Relat Res. 1989;(249):256-64

6. Guzik G. Oncological and functional results after surgical treatment of bone metastases at the proximal femur. BMC Surg. 2018;18(1):5.

7. Rebalance Focus Action Group. A position paper: screening key indicators in cancer patients: pain as a 5th vital sign and emotional distress as a 6th vital sign. Canadian Strategy for Cancer Control Bulletin. 2005;7:4

8. Decat CS, Laros JA, de Araujo TCCF. Distress Thermometer: validation of brief screening instrument to detect distress in oncology patients. Psico-USF. 2009; 14(3):253-60.

9. Holland JC, Bultz BD, National comprehensive Cancer N. The NCCN guideline for distress management: a case for making distress the sixth vital sign. J Natl Compr Canc Netw. 2007;5(1):3-7

10. Kendall J, Glaze K, Oakland S, Hansen J, Parry C. What do 1281 distress screeners tell us about cancer patients in a community cancer center? Psychooncology. 2011:20(6):594-600.

11. Carlson LE, Waller A, Groff SL, Zhong L, Bultz BD. Online screening for distress, the 6 th vital sign, in newly diagnosed oncology outpatients: randomised controlled trial of computerised vs personalised triage. Br J Cancer. 2012;107(4):617-25.

12. Riccio Al, Wodajo FM, Malawer M. Metastatic carcinoma of the long bones. Am Fam Physician. 2007;76(10):1489-94

13. Guzik G. Results of the treatment of bone metastases with modular prosthetic replacement--analysis of 67 patients. J Orthop Surg Res. 2016;11:20.

14. Jacobsen PB, Donovan KA, Trask PC, Fleishman SB, Zabora J, Baker F, et al Screening for psychologic distress in ambulatory cancer patients. Cancer. 2005;103(7):1494-502.

15. Gil F, Grassi L, Travado L, Tomamichel M, Gonzalez JR, Southern European Psycho-Oncology Study G. Use of distress and depression thermometers to measure psychosocial morbidity among southern European cancer patients. Support Care Cancer. 2005;13(8):600-6.

16. Tuinman MA, Gazendam-Donofrio SM, Hoekstra-Weebers JE. Screening and referral for psychosocial distress in oncologic practice: use of the Distress Thermometer. Cancer. 2008;113(4):870-8.

17. Lera AT, Miranda MC, Trevizan LLB, Antonangelo DV, Zanellato RM, Tateyama LTC, et al. Aplicação do instrumento termômetro de estresse em pacientes idosos com câncer: estudo piloto. Rev Bras Clin Med. 2011;9:112-26.

18. Van Hoose L, Black LL, Doty K, Sabata D, Twumasi-Ankrah P, Taylor S, et al. An analysis of the distress thermometer problem list and distress in patients with cancer. Support Care Cancer. 2015;23(5):1225-32.

19. Arnaboldi P, Riva S, Vadilonga V, Tadini L, Magon G, Pravettoni G. Distress and psychosocial needs in patients accessing a cancer day surgery division: implications for clinical decision making. Front Psychol. 2016;7:2040. 